\title{
Ob receptor in rabbit ovary and leptin in vitro regulation of corpora lutea
}

\author{
Massimo Zerani, Cristiano Boiti ${ }^{1}$, Danilo Zampini ${ }^{1}$, \\ Gabriele Brecchia ${ }^{1}$, Cecilia Dall'Aglio ${ }^{1}$, Piero Ceccarelli ${ }^{1}$ and \\ Anna Gobbetti
}

\author{
Dipartimento di Biologia molecolare, cellulare e animale, Università di Camerino, via F. Camerini 1, 62032 Camerino, Italy \\ ${ }^{1}$ Dipartimento di Scienze biopatologiche veterinarie, Università di Perugia, S. Costanzo 4, 06100 Perugia, Italy \\ (Requests for offprints should be addressed to Massimo Zerani; Email: massimo.zerani@unicam.it)
}

\begin{abstract}
We studied leptin involvement in rabbit corpora lutea (CL) activity, and its post-transcriptional signalling pathway. The expression of leptin receptor (Ob-R) in rabbit ovary at day 9 of pseudopregnancy was evaluated by immunohistochemistry and Western blot analysis. The specificity of the $\mathrm{Ob}-\mathrm{R}$ receptor antibodies was characterised by immunoprecipitation and competition with blocking peptide. Day 9 CL were incubated in vitro with leptin alone or with inhibitors of PLC (phospholipase C), PLD (phospholipase D), AC (adenylate cyclase), JAK (janus kinase), MAPK (mitogen-activated protein kinase) and both cAMP- and cGMP-specific PDE (phosphodiesterase). Prostaglandin F2 $\alpha$ (PGF2 $\alpha$ ), PGE2 and progesterone levels were measured in the culture medium, while NOS (nitric oxide synthase) and cAMP- and
\end{abstract}

cGMP- specific PDE activities were measured in CL tissue. Positive staining for $\mathrm{Ob}-\mathrm{R}$ was found within the cytoplasm of large luteal cells of CL as well as in granulosa cells of follicles and oocytes. Immunoblots detected a band of about $99 \mathrm{kDa}$ size in $\mathrm{Ob}-\mathrm{R}$ immunoprecipitates from CL homogenates. This band was not detectable after pre-incubation of the primary antibody with the immunising leptin peptide. Leptin increased PGF2 $\alpha$ and cAMPspecific PDE, decreased basal progesterone and did not affect PGE2 and NOS levels. Leptin used the JAK pathway in increasing PGF2 $\alpha$, and MAPK and cAMPspecific PDE in decreasing progesterone. This study supports a permissive luteolytic role for leptin in rabbit CL. Journal of Endocrinology (2004) 183, 279-288

\section{Introduction}

Corpus luteum (CL) is a transient endocrine gland whose primary secretory product, progesterone, is required for the establishment and maintenance of pregnancy. The principal luteotrophic and luteolitytic signals in mammals are luteinizing hormone (LH), prostaglandin F2 $\alpha$ (PGF2 $\alpha$ ) and (PGE2), however, it is becoming increasingly evident that new factors modulate the lifespan of the CL (Webb et al. 2002).

Leptin is a $16.4 \mathrm{kDa}$ cytokine encoded by the obese gene and primarily secreted by adipocytes (Zhang et al. 1994). Leptin, upon binding to specific receptors in different areas of the hypothalamus (Morash et al. 1999), is involved in the control of satiety and energy metabolism through the regulation of several neurotransmitters (Harris 2000).

An increasing body of evidence suggests, however, that leptin is also implicated in several key points of the mammalian reproductive functions (Mantzoros 2000) such as steroidogenesis (Spicer \& Francisco 1997, Agarwal et al. 1999, Brannian et al. 1999), ovulation (Cunningham et al.
1999, Ryan et al. 2002), pregnancy (Mounzih et al. 1998, Mukherjea et al. 1999) and menstrual cycles (Quinton et al. 1999, Ludwig et al. 2000). In particular, leptin may act as the critical link between adipose tissue and the reproductive system, indicating whether adequate energy reserves are present for normal reproductive function (Moschos et al. 2002).

Recently, leptin receptor (Ob-R) has been detected in various tissues of the reproductive axis such as pituitary gonadotrope cells (Jin et al. 2000); granulosa, theca and interstitial ovary cells (Karlsson et al. 1997); endometrium (Kitawaki et al. 2000) and Leydig cells (Caprio et al. 1999). The leptin receptor shows six isoforms (Ob-Ra-f) arising from mRNA splice variants (Houseknecht et al. 1998, Sweeney 2002). The extracellular and transmembrane domains are identical in Ob-Ra-d and Ob-Rf (Sweeney 2002, Zabeau et al. 2003). Ob-Rb, the receptor single long form, includes a long intracellular domain (302 amino acids) that activates the janus kinase (JAK)/signal transducer and activator of transcription (STAT) (Baumann et al. 1996, Brann et al. 2002). In particular, ligand binding 
to the $\mathrm{Ob}-\mathrm{Rb}$, which lacks intrinsic tyrosine kinase activity, results in homodimerisation of the receptors, activation of JAK2 preassociated with the receptor and the subsequent tyrosine phosphorylation of $\mathrm{Ob}-\mathrm{Rb}$ cytoplasmic tail, and, therefore tyrosine-phosphorylating STAT1, STAT3, STAT5 and STAT6 through interaction with the SH2 domain in STATs (Baumann et al. 1996). $\mathrm{Ob}-\mathrm{Ra}, \mathrm{Ob}-\mathrm{Rc}-\mathrm{d}$ and Ob-Rf have a short intracellular domain (32-42 amino acids) that can activate the MAPK pathway (Bjørbæk et al. 1997, Houseknecht et al. 1998). $\mathrm{Ob}-\mathrm{Re}$ is a soluble receptor isoform consisting of the extracellular domain only, lacking both cytoplasmatic and transmembrane domains (Lahlou et al. 2000).

To date, nothing is known about the role of leptin in rabbit CL. The present work was undertaken to localise the cell distribution of $\mathrm{Ob}-\mathrm{R}$ in different ovarian structures, and to assess in vitro the specific downstream post-transcriptional pathway used by leptin for the regulation of progesterone and PG releases, used as markers of luteal function.

\section{Materials and Methods}

\section{Animal and hormonal regimen}

Sexually mature New Zealand White female rabbits, weighing $3 \cdot 5-4 \mathrm{~kg}$, were housed individually in an indoor facility under controlled conditions of light (14 h light/ $10 \mathrm{~h}$ darkness) and temperature $\left(18^{\circ} \mathrm{C}\right)$. Each animal had free access to food and water. Pseudopregnancy was induced with $20 \mathrm{IU}$ pregnant mare serum gonadotrophin (PMSG) (Folligon, Intervet, Milan, Italy) given i.m., followed 3 days later by an i.m. injection of $0.8 \mu \mathrm{g}$ gonadotrophin-releasing hormone $(\mathrm{GnRH})$ analogue (Receptal, Hoechst-Roussel Vet, Milan, Italy). Previous experiments in our laboratory showed that this hormonal protocol was effective in inducing ovulation in does (Stradaioli et al. 1997). The day of GnRH injection was designated day 0 . All rabbits were euthanised by cervical dislocation on day 9 of pseudopregnancy. Reproductive tracts were promptly removed after sacrifice, and both ovaries and harvested CL were immediately processed for immunohistochemistry, protein expression of $\mathrm{Ob}-\mathrm{R}$, and in vitro studies. The protocols involving the care and use of animals for these experiments were approved by the Bioethics Committee of the University of Perugia.

\section{Immunohistochemistry}

For the immunohistochemical detection of $\mathrm{Ob}-\mathrm{R}$, the ovaries of three animals were fixed by immersion in $4 \%$ paraformaldehyde and $0 \cdot 1 \mathrm{M}$ phosphate-buffered saline (PBS, $\mathrm{pH} 7 \cdot 4$ ) for $24 \mathrm{~h}$ and then processed for embedding in paraffin following routine tissue preparation procedures.

Serial $7 \mu \mathrm{m}$ thick sections, mounted on poly-L-lysine coated glass slides, were brought into water through graded ethanol and microwaved for $15 \mathrm{~min}$ in $10 \mathrm{mM}$ citric acid ( $\mathrm{pH} 6.0)$ for antigen retrieval. All subsequent steps were carried out in moist chambers at room temperature. To prevent non-specific binding of primary antibody, the sections were pre-incubated for $30 \mathrm{~min}$ with normal goat serum (1:10, Santa Cruz Biotechnology, Santa Cruz, CA, USA).

The sections were left overnight with primary monoclonal antibody, mouse anti-Ob-R (1:50, sc-8391, Santa Cruz Biotechnology). This antibody is recommended for detection of short and long forms of $\mathrm{Ob}-\mathrm{R}$, as reported in the manufacturers datasheet. The next day, sections were washed in PBS and incubated with biotinylated secondary antibody to anti-mouse IgG, (1:200, Vector Laboratories, Burlingame, CA, USA) for $30 \mathrm{~min}$. After PBS washes, sections were exposed to avidin-biotin complex (ABC, Vector Elite Kit, Vector Laboratories) for $30 \mathrm{~min}$, followed by the chromogen 3,3'-diaminobenzidine tetrachloride (DAB, Vector Laboratories) for $5 \mathrm{~min}$. After washing in tap water, the luteal sections were counter-stained with haematoxylin, dehydrated and mounted in Canada Balsm Natural (BDH, Poole, Dorset, England). Positive reactions were recognised as reddish brown precipitates. Sections in which the primary antibodies were omitted or substituted by pre-immune mouse gamma globulin were used for the negative control of unspecific staining. As a further control of the specificity of the staining, sections were incubated with the primary antibody that had been pre-incubated with the corresponding antigen $(50 \mu \mathrm{g}$ of the blocking peptide (sc-8391 P, Santa Cruz Biotechology) in $1 \mathrm{ml}$ of the working solution).

\section{Western blot analysis}

For Western blot analysis of the Ob-R proteins, CL were collected from the ovaries of two rabbits. Non-luteal tissue was carefully dissected away with fine forceps under stereoscopic magnification. For each rabbit, total luteal proteins were extracted from a pool of $10 \mathrm{CL}$ that was homogenised in $1 \mathrm{ml}$ of ice-cold RIPA buffer (PBS containing 1\% Igepal CA-630, 0.5\% sodium deoxycholate, $0 \cdot 1 \%$ SDS) with added EDTA-free protease inhibitor cocktail (Roche, Mannheim, Germany) using an Omni- $\mu \mathrm{U}$ mixer (Analytical Control, Dasit, Milan, Italy). After incubation at $4{ }^{\circ} \mathrm{C}$ for $20 \mathrm{~min}$, the homogenates were centrifuged at $25000 \times \boldsymbol{g}$ for $60 \mathrm{~min}$ at $4{ }^{\circ} \mathrm{C}$. The supernatants were collected and their protein concentrations measured using the Protein Assay Kit (Bio-Rad Laboratories Inc., Hercules, CA, USA) with BSA as standard. Total luteal protein extracts were appropriately diluted with PBS at a final concentration of $500 \mu \mathrm{g} / \mathrm{ml}$.

Two $\mu \mathrm{g}$ of goat anti-Ob-R antibody (sc-1834, antibody for detection of short and long forms of Ob-R, Santa Cruz Biotechnology) was then added to an aliquot of $500 \mu \mathrm{g}$ luteal proteins and gently stirred overnight at $4{ }^{\circ} \mathrm{C}$. After incubation, $50 \mu \mathrm{l}$ of agarose-protein $\mathrm{G}$ slurry 
(sc-2002, Santa Cruz Biotechnology) was added to each sample and stirred in an ice-cold bath for $40 \mathrm{~min}$. Following centrifugation $(2500 \mathrm{~g}$ for $2 \mathrm{~min}$ ), the pellets containing the immunoprecipitated proteins were washed two times with cold PBS and re-suspended in $50 \mu \mathrm{PBS}$. The supernatants, containing soluble proteins, were also collected. Thereafter, $50 \mu \mathrm{l}$ Laemmli sample buffer was added to $50 \mu \mathrm{l}$ suspended pellet and $50 \mu \mathrm{l}$ supernatant-derived solution and boiled for 4 min.

For each luteal protein extract processed, two equivalent volumes $(20 \mu \mathrm{l})$ from pellet- and supernatant-derived solutions were electrophoretically separated in duplicate by discontinuous $10 \%$ SDS-PAGE with $4 \%$ staking gel for $40 \mathrm{~min}$ at $200 \mathrm{~V} / 500 \mathrm{~mA}$, after which proteins were transferred onto a nitrocellulose membrane (Protran BA 85, Schleicher \& Schuell, Dassel, Germany) for $1 \mathrm{~h}$ at $100 \mathrm{~V} / 350 \mathrm{~mA}$. After transfer, membranes were blocked with PBS containing $0.5 \%$ casein (PBSC). The first membrane was incubated overnight at $4{ }^{\circ} \mathrm{C}$ with antiOb-R monoclonal antibodies (1:100, sc-8391, Santa Cruz Biotechnology). The second membrane was similarly incubated with the same $\mathrm{mAb}$ anti-Ob-R that was preadsorbed for $3 \mathrm{~h}$ at $4{ }^{\circ} \mathrm{C}$ with its blocking peptide $(10 \mu \mathrm{g}$ of antigen in $1 \mathrm{ml}$ of the working solution).

Membranes were then probed with a chicken antimouse IgG-peroxidase antibody (Santa Cruz Biotechnology) at 1:2000 dilution for $60 \mathrm{~min}$ at room temperature under gentle agitation. All antibody incubations were performed in PBSC and washings in PBS with $0.05 \%$ Tween-20. Immunoreactive bands were developed using $4 \mathrm{CN}$ substrate for peroxidase (Bio-Rad Laboratories) at room temperature for $20 \mathrm{~min}$. Pre-stained SDS-PAGE MW Standards (Bio-Rad Laboratories, Dual Color Standard) were used as molecular weight references. Blot images were acquired with HP scanner.

\section{In vitro incubations}

CL were randomly distributed (one CL/well) into incubation wells (Becton Dickinson Co., Clifton, NJ, USA) in $1 \mathrm{ml}$ of culture medium 199 with Earles Balanced Salt Solution (GIBCO, Grand Island, NY, USA) containing $2.2 \mathrm{mg} / \mathrm{ml}$ sodium bicarbonate, $2.3 \mathrm{mg}$ HEPES (Sigma, St Louis, MO, USA), and 3\% BSA (Sigma), referred to here as M199. Before treatment, the CL were quartered inside each well using fine forceps. Each incubation set of wells was divided into 12 experimental groups of 5 wells as follows: (I) medium alone as control; (II) leptin (100 nM, Calbiochem Corporation, San Diego, CA, USA); (III) leptin plus PGF2 $\alpha$ ( $3 \mu \mathrm{M}$, Sigma); (IV) leptin plus PLC inhibitor (compound 48/80, $2 \mu \mathrm{M}$, Sigma); (V) leptin plus PLD inhibitor (propranolol, $10 \mu \mathrm{M}$, Sigma); (VI) leptin plus AC inhibitor (2-O-methyladenosine, $2 \mu \mathrm{M}$, Sigma); (VII) leptin plus JAK inhibitor (AG490, $2 \mu \mathrm{M}$, Calbiochem Corporation); (VIII) leptin plus MAPK/extracellular signal-regulated kinase kinase 1 and
2 (MEK1/2) inhibitor (English et al. 2002) (PD98059, $10 \mu \mathrm{M}$, Tocris); (IX) leptin plus cAMP specific PDE inhibitor (zardaverine, $2 \mu \mathrm{M}$, Tocris); (X) leptin plus cGMP specific PDE inhibitor (zaprinast, $2 \mu \mathrm{M}$, Tocris); (XI) PGF2 $\alpha$ plus cAMP-specific PDE inhibitor; (XII) PGF2 $\alpha$ plus cGMP-specific PDE inhibitor. The culture plates were incubated at $37{ }^{\circ} \mathrm{C}$ in air with $5 \% \mathrm{CO}_{2}$ as reported elsewhere (Gobbetti et al. 1999, Boiti et al. 2000). The media of each well were collected after $4 \mathrm{~h}$ of incubation and stored immediately at $-20{ }^{\circ} \mathrm{C}$ for later determination of hormones. CL were weighed and stored immediately at $-20{ }^{\circ} \mathrm{C}$ for later determination of NOS and PDE activities. Preliminary evidence led to our choosing the incubation conditions and the minimum effective doses of the substances used in the present in vitro study (data not shown).

\section{Phosphodiesterase assay}

Cyclic AMP-and cGMP-specific PDE activities were assessed by using the two-step assay as previously reported (Hermsdorf \& Dettmer 1998). Half the CL of each well were homogenised in $1 \mathrm{ml}$ of cold fresh homogenating buffer $(50 \mathrm{mM}$ Tris, $1 \mathrm{mM}$ EDTA and $1 \mathrm{mM}$ EGTA, $\mathrm{pH} 7 \cdot 4$ ), and centrifuged at $20000 \times \boldsymbol{g}$ for $60 \mathrm{~min}$ at $4{ }^{\circ} \mathrm{C}$. Incubation was performed in a total volume of $300 \mu \mathrm{l}$ $100 \mathrm{mM}$ Tris- $\mathrm{HCl}$ (pH 7.4), $5 \mathrm{mM} \mathrm{MgCl}_{2}, 3.75 \mathrm{mM}$ mercaptoethanol with 100000 d.p.m. $\left[{ }^{3} \mathrm{H}\right]$ cAMP or $\left[{ }^{3} \mathrm{H}\right]$ cGMP (Sigma) for $20 \mathrm{~min}$ at $30^{\circ} \mathrm{C}$. The reaction was stopped by boiling the mixtures for $3 \mathrm{~min}$. After cooling in an ice bath, samples were incubated for $15 \mathrm{~min}$ at $30{ }^{\circ} \mathrm{C}$ in 0.3 alkaline phosphate followed by inactivation by $3 \mathrm{~min}$ in boiling water. To separate $\left[{ }^{3} \mathrm{H}\right]$ adenosine from $\left[{ }^{3} \mathrm{H}\right]$ cAMP or $\left[{ }^{3} \mathrm{H}\right]$ guanosine from $\left[{ }^{3} \mathrm{H}\right] \mathrm{cGMP}, 1 \mathrm{ml}$ of a slurry (DOWEX $1 \times 2200-400$ mesh, Cl form, resin:water $1: 4 \mathrm{v} / \mathrm{v}$, Sigma) was added and mixed for $1 \mathrm{~min}$. After centrifugation for $3 \mathrm{~min}$ at $12000 \times \boldsymbol{g}, 250 \mu \mathrm{l}$ of supernantant was transferred into vial for liquid scintillation counting. Recovery of the ${ }^{3} \mathrm{H}$-labelled products was estimated by using $\left[{ }^{3} \mathrm{H}\right]$ adenosine or $\left[{ }^{3} \mathrm{H}\right]$ guanosine (data not shown). Protein concentration was determined by BioRad Protein Assay Kit (Bio-Rad, Hercules, CA, USA).

\section{NO synthase activity determination}

NOS activity was determined, in the CL used for in vitro incubations, by monitoring the conversion of $\left[{ }^{3} \mathrm{H}\right] \mathrm{L}-$ arginine into $\left[{ }^{3} \mathrm{H}\right] \mathrm{L}$-citrulline with the NOS detect Assay Kit (Alexis Corporation, Läufelfingen, Switzerland) (Boiti et al. 2000). Half the CL of each well was homogenised in $1 \mathrm{ml}$ of cold fresh homogenating buffer $(50 \mathrm{mM}$ Tris, $1 \mathrm{mM}$ EDTA and $1 \mathrm{mM} \mathrm{EGTA}, \mathrm{pH} 7 \cdot 4$ ), and centrifuged at $20000 \times \boldsymbol{g}$ for $60 \mathrm{~min}$ at $4{ }^{\circ} \mathrm{C}$. Twenty-five microlitres of supernatant and $100 \mu \mathrm{l}$ of incubation buffer $(1.5 \mathrm{mM}$ NADPH, $1 \mathrm{mM} \mathrm{CaCl}_{2}$ ) containing 150000 d.p.m. $\left[{ }^{3} \mathrm{H}\right] \mathrm{L}$-arginine (Sigma) were added to the incubation tube. 
After 30 min incubation at room temperature, the enzymatic reaction was stopped by the addition of $2 \mathrm{ml}$ of blocking buffer (20 mM HEPES, 2 mM EDTA, pH 5.5). The mixture was applied to a pre-equilibrated column (20 mM sodium acetate, $2 \mathrm{mM}$ EDTA, 0.2 mM EGTA, $\mathrm{pH} 5 \cdot 5 ; 1 \mathrm{~cm}$ diameter) containing $1 \mathrm{ml}$ of Dowex AG50W-X8 (Sigma) and the material was eluted with $2 \mathrm{ml}$ of water. $\left[{ }^{3} \mathrm{H}\right] \mathrm{L}-$ Citrulline was quantified in a liquid scintillation system LS 1801 (Beckman Instruments, Fullerton, CA, USA). Additional determinations were performed in the presence of excess of NOS inhibitor (L-NAME, Sigma) to verify the specificity of the assay for production of $\left[{ }^{3} \mathrm{H}\right] \mathrm{L}$-citrulline by NOS (data not shown). Protein concentration was determined by BioRad Protein Assay Kit.

\section{Hormone radioimmunoassay}

PGF2 $\alpha$, PGE2 and progesterone were determined in the medium samples following the RIA previously reported (Boiti et al. 2000). Intra- and inter-assay coefficients of variation and minimum detectable dose were PGF2 $\alpha$ : 8\%, 12\%, 19 pg; PGE2: 7\%, 13\%, 18 pg; progesterone: $5 \%, 9 \%, 10$ pg. PGF2 $\alpha$, PGE2, progesterone antisera and non-radioactive hormones were purchased from Sigma (St Louis, MO, USA). Tritiated hormones were purchased from Amersham International (Amersham, Buckinghamshire, UK).

\section{Statistics}

Data relative to hormone releases and enzymatic activities were analysed by an analysis of variance (ANOVA) (Sokal \& Rohlf 1981) followed by Duncan's multiple range test (Duncan 1955).

\section{Results}

\section{Immunolocalization of $\mathrm{Ob}-\mathrm{R}$}

Using a monoclonal antibody, positive staining for $\mathrm{Ob}-\mathrm{R}$ was detected in the ovary of pseudopregnant rabbits. Within the ovary, strong Ob-R-like immunoreactivity was found in granulosa cells of primary, secondary and tertiary follicles and in oocytes (Fig. 1, panel A). Within the CL, a strong positive reaction for $\mathrm{Ob}-\mathrm{R}$ was localised primarily in the large luteal cells as indicated by the staining in their cytoplasm (Fig. 1, panel B) and also in the thecal layer cells, although less evident. Staining was completely abolished when the primary antibody was substituted with non-immune serum or pre-adsorbed with the blocking peptide (data not shown).

\section{Western blot analysis}

Western blot analysis of $\mathrm{Ob}-\mathrm{R}$ protein expression revealed a strong band of approximately $99 \mathrm{kDa}$ size only in the immunoprecipitated-derived fraction from whole luteal protein extracts of the two rabbits examined (Fig. 2, left). As expected, in the supernatant-derived samples (Ob-Rstripped fraction), the corresponding $99 \mathrm{kDa}$ band was not visible. Pre-incubation of $\mathrm{mAb}$ anti $\mathrm{Ob}-\mathrm{R}$ of mouse origin with the immunising peptide completely neutralised the primary antibody as a band of comparable size was not detectable (Fig. 2, right).

In vitro cultured corpora lutea

Hormones Leptin increased PGF2 $\alpha(P \leq 0 \cdot 01)$ (Fig. 3) and decreased progesterone $(P \leq 0 \cdot 01)$ (Fig. 4$)$ release in in vitro cultured CL. PGF2 $\alpha$ decreased progesterone release $(P \leq 0 \cdot 01)$ (Fig. 4). The progesterone decreasing induced by leptin was lower $(P \leq 0 \cdot 01)$ than those induced by PGF2 $\alpha$ (Fig. 4). JAK inhibitor counteracted $(P \leq 0 \cdot 01)$ the leptin effects on PGF2 $\alpha$ release (Fig. 3), while MEK1/2 and cAMP-specific PDE inhibitors counteracted $(P \leq 0 \cdot 01)$ those on progesterone (Fig. 4). PLC, PLD, AC and cGMP-specific PDE inhibitors did not affect the leptin effects on hormone release (Figs. 3, 4). In all experimental groups PGE2 release did not change (data not shown).

Enzymes Leptin increased cAMP-specific PDE activity $(P \leq 0 \cdot 01)$, while PGF2 $\alpha$ did not affect the activities of either PDE (Fig. 5). Leptin did not affect NOS activity, whereas PGF2 $\alpha$ increased enzyme activity $(P \leq 0 \cdot 01)$ (data not shown).

\section{Discussion}

The present study, for the first time, indicates the presence of $\mathrm{Ob}-\mathrm{R}$ in the ovaries of pseudopregnant rabbits, within the cytoplasm of large luteal cells of the CL, in granulosa cells of follicles at different stages of development and in oocytes. Our findings, which are similar to those obtained recently in other species, support a direct role of leptin in the regulation of several ovarian functions. In fact, Ob-R has been identified in the adult human ovaries (Cioffi et al. 1996, 1997) and rat ovaries (Zamorano et al. 1997), human granulosa and theca cells (Karlsson et al. 1997, Agarwal et al. 1999 ), mouse oocytes (Matsuoka et al. 1999) and porcine CL (Lin et al. 2000, Ruiz-Cortes et al. 2000). Our $\mathrm{HIC}$ data confirm that $\mathrm{Ob}-\mathrm{R}$ are mainly internalised after binding to its agonist as reported by Barr et al. (1999).

Western blotting of the immunoprecipitated protein fractions derived from luteal extracts yielded a strong band at $99 \mathrm{kDa}$ when probed with a mAb raised against a peptide mapping at the carboxy terminus of $\mathrm{Ob}-\mathrm{R}$ of mouse origin. The immunoprecipitation of CL extracts with an affinity-purified goat polyclonal antiserum raised against peptides corresponding to amino acids $32-51$ and 877-894, mapping respectively at the amino- and carboxytermini of mouse $\mathrm{Ob}-\mathrm{R}$, greatly improved the efficiency of the Western blotting. The addition of the blocking peptide 

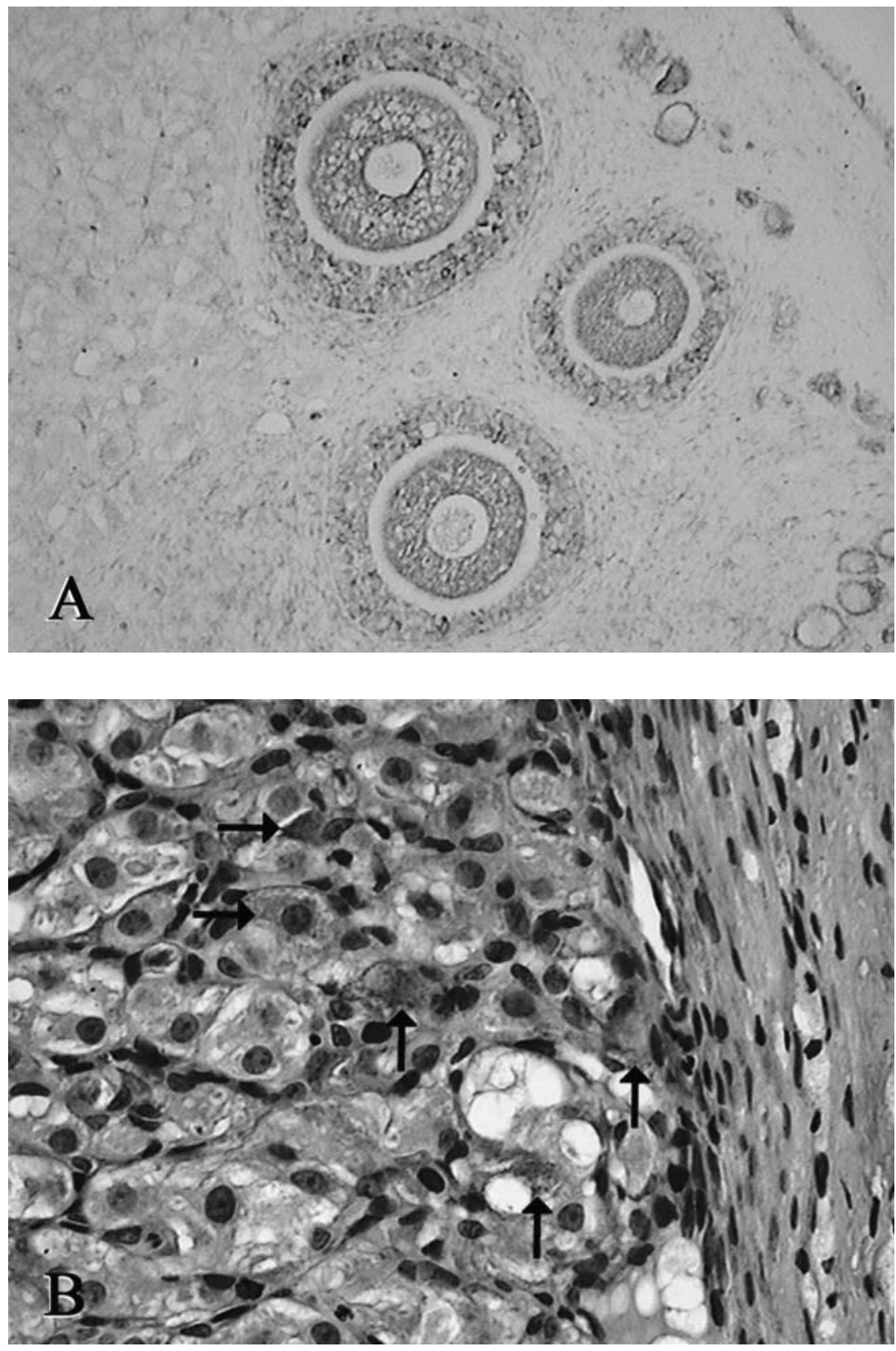

Figure 1 Immunohistochemical localisation of leptin receptor (Ob-R) in the ovary (panel A) and in the corpus luteum (panel B) of pseudopregnant rabbits. In the ovary $(\times 250)$ Ob-R is observed in the granulosa cells and in the oocyte cytoplasm of follicles at different stages of development. In the $C L(\times 1000)$ the positive reaction (arrows) is evident in the cytoplasm of both large luteal and thecal layer cells.

to the primary antibody completely masked the target $99 \mathrm{kDa}$ band, thus indirectly confirming the specificity of the antibodies here employed to evaluate Ob-R of rabbit origin. As the sequence of rabbit $\mathrm{Ob}-\mathrm{R}$ gene is still unknown, its similarity with mouse Ob-R transcript, used to raise both the polyclonal and monoclonal antibodies here employed, remains to be disclosed. However, it should be noted that for the region of the $\mathrm{Ob}-\mathrm{R}$ that the primary monoclonal $\operatorname{IgG}$ was directed against, there is a $100 \%$ identity, exact amino acid sequence, for mouse, rat, human, pig and rhesus monkey (personal communication from Santa Cruz Biotechnology). To the best of our 
$\mathbf{A}$

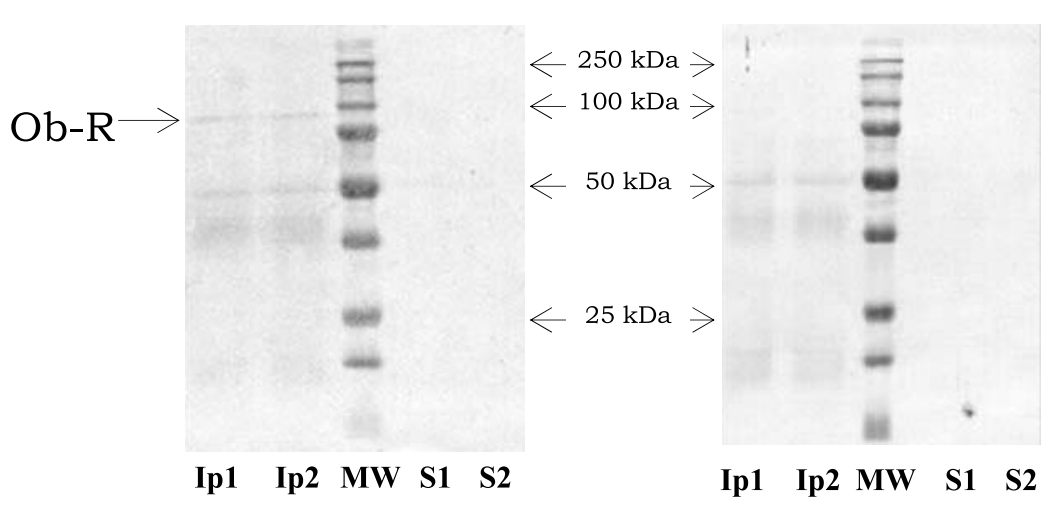

Figure 2 Representative Western blots of Ob-R protein in the Ob-R immunoprecipitated fractions from whole homogenates of $\mathrm{CL}$ collected at day 9 of pseudopregnancy from two rabbits (Ip1 and Ip2) and in the corresponding Ob-R-stripped fractions (S1 and S2). MW identifies the molecular weight standards. Blots of membrane $A$ were incubated with primary $\mathrm{mAb}$ anti Ob-R of mouse origin, whereas those of membrane $B$ were tested with the same $\mathrm{mAb}$ pre-incubated with its immunising peptide. The left immunoblot (membrane A, Ip1 and Ip2) shows Ob-R specific bands at an apparent MW of $99 \mathrm{kDa}$. Experiments were performed at least three times.

\section{PGF2 $\alpha$ release by CL cultured in vitro}

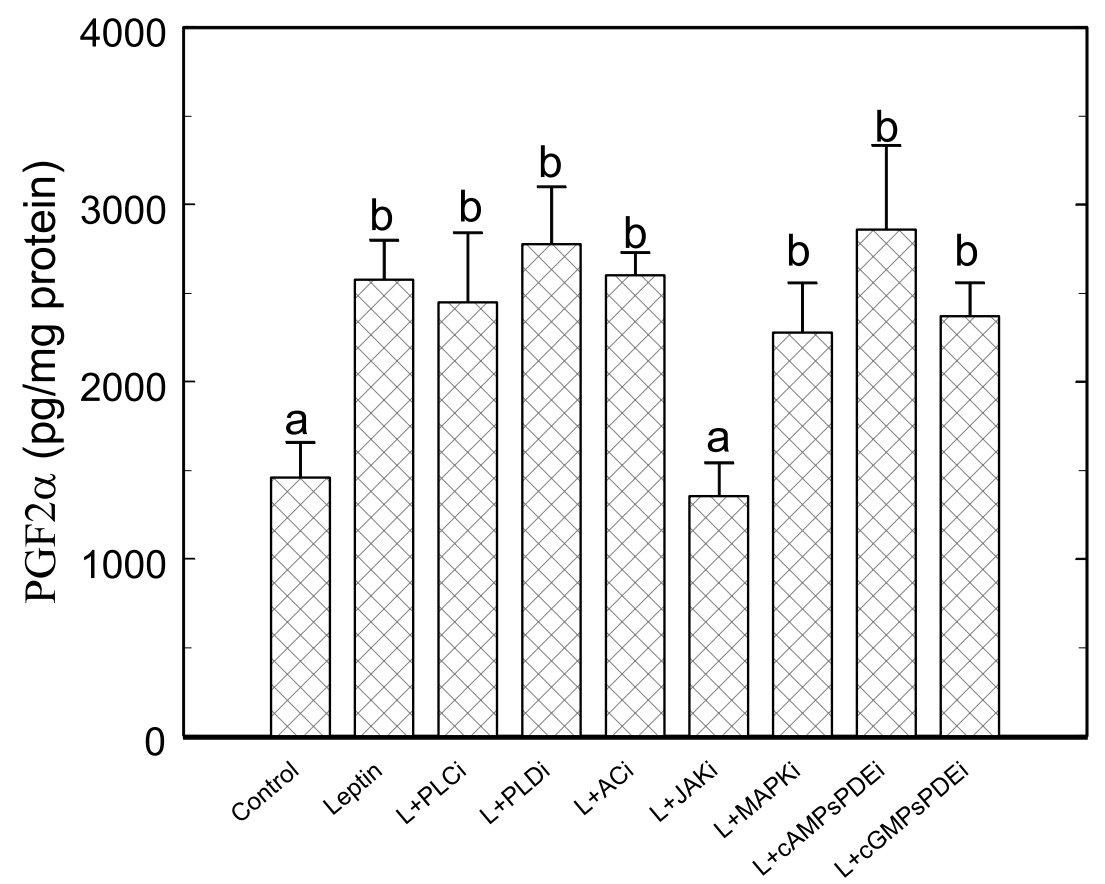

Figure 3 In vitro effects of leptin (L) and L co-incubated with inhibitors of PLC, PLD, AC, JAK, MEK1/2, CAMP-specific PDE, and cGMP-specific PDE on PGF2 $\alpha$ release by pseudopregnant rabbit CL. Results are the means \pm S.D. of five replicate values. Different letters above the bars indicate significantly different values $(P \leqslant 0 \cdot 01$, Duncan's multiple range test). 


\section{Progesterone release by CL cultured in vitro}

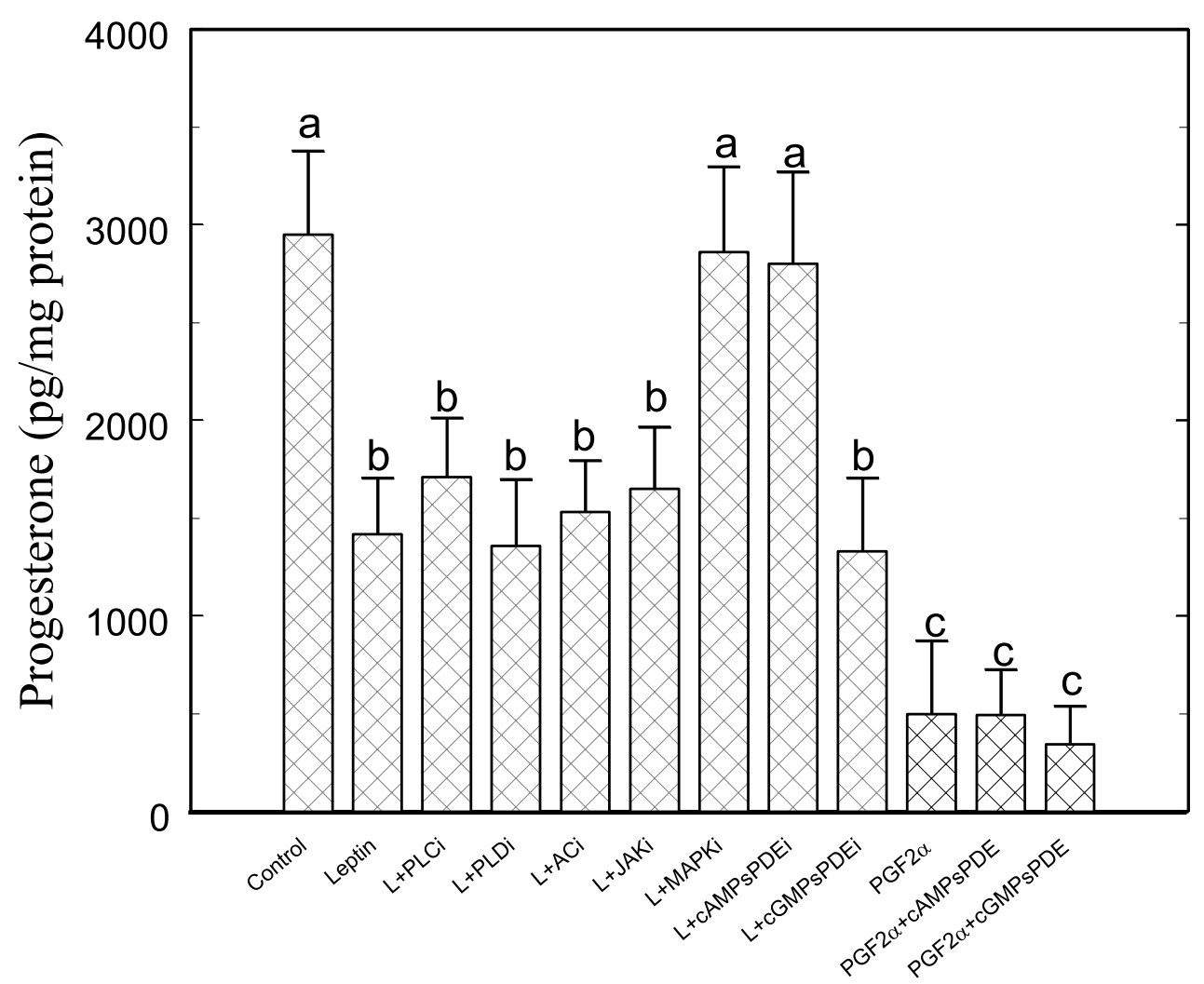

Figure 4 In vitro effects of leptin (L), PGF2 $\alpha$ and inhibitors of PLC, PLD, AC, JAK, MEK1/2, CAMP-specific PDE and CGMP-specific PDE on progesterone release by pseudopregnant rabbit CL. Results are the means \pm S.D. of five replicate values. Different letters above the bars indicate significantly different values $(P \leqslant 0 \cdot 01$, Duncan's multiple range test).

knowledge this is the first report on Ob-R expression in rabbits and, therefore, comparative analysis with results obtained in other species is of limited relevance. Since both Ob-R antibodies used for Western blot recognise all transmembrane $\mathrm{Ob}-\mathrm{R}$ splice variants, it remains to be established which type of leptin receptors, either long or short, is indeed expressed in the ovary of rabbits.

Recent studies carried out on theca, granulosa and luteinised granulosa cells show that leptin in vitro exerts a direct inhibition on rodent, bovine and primate steroidogenesis intracellular signalling pathway (Karlsson et al. 1997, Spicer \& Francisco 1997, 1998, Zachow \& Magoffin 1997, Agarwal et al. 1999, Brannian et al. 1999). Similarly, our study suggests that leptin in vitro affects steroidogenesis in rabbit too, and in fact this hormone decreases progesterone basal release by CL. In untreated human luteinised granulosa cells, leptin has no effect on progesterone basal synthesis, but it has been shown to decrease progesterone production only when stimulated with human chorionic gonadotrophin (Brannian et al. 1999).
Nothing is known about leptin effects on PG release, except that this hormone stimulates PGE2 and PGF2 $\alpha$ in rat hypothalamus (Brunetti et al. 1999). The present work shows a direct effect of leptin on PG release by rabbit CL, given that PGF2 $\alpha$ release is increased by leptin in vitro. Differently from Brunetti et al. (1999) however, leptin had no effect on PGE2.

From our data, it emerges that leptin uses different intracellular signalling pathways in affecting progesterone and PGF2 $\alpha$. In fact, leptin exhibits an inhibitory effect on progesterone through MAPK cascade and a stimulatory one on PGF2 $\alpha$, through JAK in rabbit CL. These results suggest that leptin could use different receptors (long $\mathrm{Ob}-\mathrm{R}$ and short $\mathrm{Ob}-\mathrm{R}$ ?) and/or affect different (small and large?) CL cells in the modulation of progesterone and PGF2 $\alpha$ release by rabbit CL. However, because the co-expression of both long and short types of leptin receptor is not supported by immunoblot analysis of luteal homogenates, these intriguing results need further study, given that the long isoform has well-known signalling 


\section{PDE activities in CL cultured in vitro}

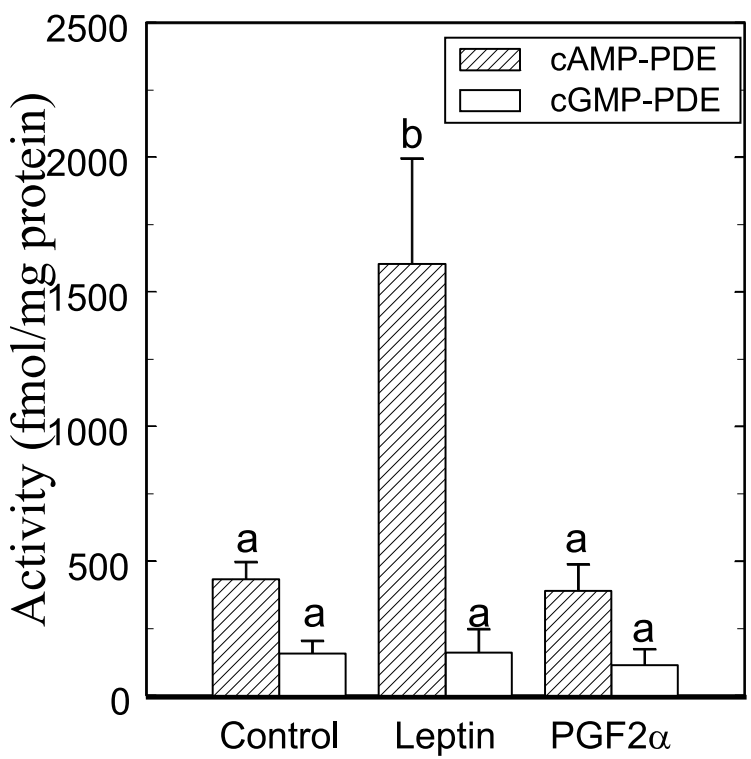

Figure 5 In vitro effects of leptin and PGF2 $\alpha$ on cAMP-specific and cGMP-specific PDE activities in pseudopregnant rabbit CL. Results are the means \pm S.D. of five replicate values. Different letters above the bars indicate significantly different values $(P \leqslant 0 \cdot 01$, Duncan's multiple range test).

capability, whereas the short form is largely expressed in different tissues (Tartaglia 1997).

Recently, Cauzac et al. (2003) reported that leptin stimulated the transcription of the $c-f o s$ gene and cell proliferation in human placental cells through the rapid phosphorylation of p42-44 MAPK, while the JAK/STAT pathway is not required for leptin to transduce proliferative signals in these cells.

There are two main mechanisms regulating the signal transduction in the MAPK cascades: the docking interaction and the scaffolding (Tanoue \& Nishida 2003). The docking interaction is achieved through specific conserved regions on MAPKs and MAPK-interacting molecules. Scaffolding generally requires a third molecule to join enzyme and substrate (Tanoue \& Nishida 2003). PDE is a substrate of MAPKs and shows a specific conserved motif for the docking interaction (Mackenzie et al. 2000, Fantz et al. 2001, Tanoue \& Nishida 2003).

The effects of leptin on progesterone release by rabbit CL suggest that the MAPK could regulate its signal through interaction with a cAMP-specific PDE, in fact, the inhibitor of this PDE counteracted the progesterone decrease induced by leptin. In a recent study it was proposed that PDE4 (cAMP-specific PDE) isoenzymes integrate cAMP and p42 MAPK intracellular signal transducing and that these isoenzymes may be activated, inhibited or insensitive to p42 MAPK (Baillie et al. 2000). In particular, Baillie et al. (2001) suggest that PDE4D isoenzyme is activated by protein kinase A through a process ablated by the MEK1/2 inhibitor PD98059 in human aortic smooth muscle cells.

Due to the existing cross-talk and interference between different MAPK modules in transducing intracellular signals, the antisteroidogenic action evoked in vitro by leptin might also have been elicited by the stress-activated JNK/p38/MAPK pathways leading to apoptosis of luteal cells (Cano \& Mahadevan 1995).

Nitric oxide is deeply involved in the regulation of rabbit CL function, as PGE2 exerts its luteotrophic effect through NOS down-regulation while the PGF2 $\alpha$ luteolytic effect is mediated by NOS up-regulation (Boiti et al. 2000). Present results show that PGF2 $\alpha$ increased the enzymatic activity of NOS in agreement with what we found in previous studies (Boiti et al. 2000). Leptin, however, does not exert any influence on luteal NOS activity, at least under present experimental conditions. Leptin increased PGF2 $\alpha$ CL release, but probably this prostaglandin increase did not reach the threshold to affect NOS activity.

Finally, although considerable progress has been achieved in understanding the reproductive actions of leptin over the past few years, much work is needed before we can arrive at a complete understanding of its physiological role, if any, in controlling the life span of rabbit CL. At the moment our data, based on the observation that this hormone increases PGF2 $\alpha$ and decreases progesterone release by rabbit CL in vitro, suggest a permissive luteolytic role for leptin, whose physiological relevance remains to be better elucidated. This hypothesis might be indirectly suggested by the findings that luteolysis is impaired in feed-restricted gilts when circulating leptin levels are low. In fact, plasma progesterone was significantly higher in fasting than in full-fed gilts from 5 to $53 \mathrm{~h}$ after the induction of luteolysis by the prostaglandin analogue, alfaprostol (Prunier \& Quesnel 2000). Caprio et al. (2001) have proposed that leptin has a dual action on mammal reproductive function, determined by different thresholds and by its site of activity. Leptin concentrations above a minimal threshold are necessary in the hypothalamus to activate the hypothalamus-pituitary-gonadal axis, for triggering puberty and maintaining normal reproductive function. Leptin excess above a certain threshold, such as is found in obesity, might impair testicular and ovarian steroidogenesis and have deleterious effects on reproduction (Caprio et al. 2001). The in vitro effects of leptin on rabbit CL seem in agreement with the current view on the role of leptin in considering that this hormone has showed a permissive luteolytic role.

\section{Acknowledgements}

This work was supported by grants from 'Ministero dell'Istruzione, Università e Ricerca'. 


\section{References}

Agarwal SK, Vogel K, Weitsman SR \& Magoffin DA 1999 Leptin antagonizes the insulin-like growth factor-I augmentation of steroidogenesis in granulosa and theca cells of the human ovary. Journal of Clinical Endocrinology and Metabolism 84 1072-1076.

Baillie GS, MacKenzie SJ, McPhee I \& Houslay MD 2000 Sub-family selective actions in the ability of Erk2 MAP kinase to phosphorylate and regulate the activity of PDE4 cyclic AMP-specific phosphodiesterases. British Journal of Pharmacology 131 811-819.

Baillie G, MacKenzie SJ \& Houslay MD 2001 Phorbol 12-myristate 13-acetate triggers the protein kinase A-mediated phosphorylation and activation of the PDE4D5 cAMP phosphodiesterase in human aortic smooth muscle cells through a route involving extracellular signal regulated kinase (ERK). Molecular Pharmacology 60 1100-1111.

Barr VA, Lane K \& Taylor SI 1999 Subcellular localization and internalization of the four human leptin receptor isoforms. Journal of Biological Chemistry 274 21416-21424.

Baumann H, Morella KK, White DW, Dembski M, Bailon PS, Kim H, Lai CF \& Tartaglia LA 1996 The full-length leptin receptor has signaling capabilities of interleukin 6-type cytokine receptors. PNAS 9 8374-8378.

Bjørbæk AS, Uotani S, da Silva B \& Flier JS 1997 Divergent signaling capacities of the long and short isoforms of the leptin receptor. Journal of Biological Chemistry 272 32686-32695.

Boiti C, Zerani M, Zampini D \& Gobbetti A 2000 Nitric oxide synthase activity and progesterone release by isolated corpora lutea of rabbits in the early and mid-luteal phases of pseudopregnancy are modulated differently by prostaglandin E-2 and prostaglandin F-2 alpha via adenylate cyclase and phospholipase C. Journal of Endocrinology 164 179-186.

Brann DW, Wade FM, Dhandapani KM, Mahesh VB \& Buchanan CD 2002 Leptin and reproduction. Steroids 67 95-104.

Brannian JD, Zhao Y \& McElroy M 1999 Leptin inhibits gonadotrophin-stimulated granulosa cell progesterone production by antagonizing insulin action. Human Reproduction 14 1445-1448.

Brunetti L, Orlando G, Michelotto B, Regazzoni E \& Vacca M 1999 Leptin stimulates prostaglandin E2 and F2 alpha, but not nitric oxide production in neonatal rat hypothalamus. European Journal of Pharmacology 369 299-304.

Cano E \& Mahadevan LC 1995 Parallel signal processing among mammalian MAPKs. Trends in Biochemical Science 20 117-122.

Caprio M, Isidori AM, Carta AR, Moretti C, Dufau ML \& Fabbri A 1999 Expression of functional leptin receptors in rodent Leydig cells. Endocrinology 140 4939-4947.

Caprio M, Fabbrini E, Isidori AM, Aversa A \& Fabbri A 2001 Leptin in reproduction. Trends in Endocrinology and Metabolism 12 65-72.

Cauzac M, Czuba D, Girard J \& Hauguel-de Mouzon S 2003 Transduction of leptin growth signals in placental cells is independent of JAK-STAT activation. Placenta 24 378-384.

Cioffi JA, Shafer AW, Zupancic TA, Smith-Gbur J, Mikhail A, Platika D \& Snodgrass HR 1996 Novel B219/OB receptor isoforms: possible role of leptin in hematopoiesis and reproduction. Nature Medicine 2 585-589.

Cioffi JA, Van Blerkom J, Antczak M, Shafer A, Wittmer S \& Snodgrass HR 1997 The expression of leptin and its receptors in pre-ovulatory human follicles. Molecular Human Reproduction $\mathbf{3}$ $467-472$.

Cunningham MJ, Clifton DK \& Steiner RA 1999 Leptin's actions on the reproductive axis: perspectives and mechanisms. Biology of Reproduction 60 216-222.

Duncan DB 1955 Multiple range and multiple F test. Biometrics 11 $1-42$.

English JM \& Cobb MH 2002 Pharmacological inhibitors of MAPK pathways. Trends in Pharmacological Sciences 23 40-45.

Fantz DA, Jacobs D, Glossip D \& Kornfeld K 2001 Docking sites on substrate proteins direct extracellular signal-regulated kinase to phosphorylate specific residues. Journal of Biological Chemistry 276 27256-27265.

Gobbetti A, Boiti C, Canali C \& Zerani M 1999 Nitric oxide synthase acutely regulates progesterone production by in vitro cultured rabbit corpora lutea. Journal of Endocrinology 160 275-283.

Harris RB 2000 Leptin-much more than a satiety signal. Annual Review of Nutrition 20 45-75.

Hermsdorf T \& Dettmer D 1998 Combinated effects of insulin and dexamethasone on cyclic AMP Phosphodiesterase 3 and glycogen metabolism in cultured rat hepatocytes. Cellular Signalling $\mathbf{1 0}$ 629-635.

Houseknecht KL \& Portocarrero CP 1998 Leptin and its receptors: regulators of whole-body energy homeostasis. Domestic Animal Endocrinology 15 457-475.

Jin L, Zhang S, Burguera BG, Couce ME, Osamura RY, Kulig E \& Lloyd RV 2000 Leptin and leptin receptor expression in rat and mouse pituitary cells. Endocrinology 141 333-339.

Karlsson C, Lindell K, Svensson E, Bergh C, Lind P, Billig H, Carlsson LM \& Carlsson B 1997 Expression of functional leptin receptors in the human ovary. Journal of Clinical Endocrinology and Metabolism 82 4144-4148.

Kitawaki J, Koshiba H, Ishihara H, Kusuki I, Tsukamoto K \& Onjo HH 2000 Expression of leptin receptor in human endometrium and fluctuation during the menstrual cycle. Journal of Clinical Endocrinology and Metabolism 85 1946-1950.

Lahlou N, Clement K, Carel JC, Vaisse C, Lotton C, LeBihan Y, Basdevant A, Lebouc Y, Froguel P, Roger M \& Guy-Grand B 2000 Soluble leptin receptor in serum of subjects with complete resistance to leptin: relation to fat mass. Diabetes 49 1347-1352.

Lin J, Barb CR, Matteri RL, Kraeling RR, Chen X, Meinersmann RJ \& Rampacek GB 2000 Long form leptin receptor mRNA expression in the brain, pituitary, and other tissues in the pig. Domestic Animal Endocrinology 19 53-61.

Ludwig M, Klein HH, Diedrich K \& Ortmann O 2000 Serum leptin concentrations throughout the menstrual cycle. Archives of Gynecology and Obstetrics 263 99-101.

MacKenzie SJ, Baillie GS, McPhee I, Bolger GB \& Houslay MD 2000 ERK2 mitogen-activated protein kinase binding, phosphorylation, and regulation of the PDE4D cAMP-specific phosphodiesterases - the involvement of $\mathrm{COOH}$-terminal docking sites and NH2-terminal UCR regions. Journal of Biological Chemistry 275 16609-16617.

Mantzoros CS 2000 Role of leptin in reproduction. Annals of the New York Academy of Sciences 900 174-183.

Matsuoka T, Tahara M, Yokoi T, Masumoto N, Takeda T, Yamaguchi M, Tasaka K, Kurachi H \& Murata Y 1999 Tyrosine phosphorylation of STAT3 by leptin through leptin receptor in mouse metaphase 2 stage oocyte. Biochemical and Biophysical Research Communications 256 480-484.

Morash B, Li A, Murphy PR, Wilkinson M \& Ur E 1999 Leptin gene expression in the brain and pituitary gland. Endocrinology 140 5995-5998.

Moschos S, Chan JL \& Mantzoros CS 2002 Leptin and reproduction: a review. Fertility and Sterility 77 433-444.

Mounzih K, Qiu J, Ewart-Toland A \& Chehab FF 1998 Leptin is not necessary for gestation and parturition but regulates maternal nutrition via a leptin resistance state. Endocrinology 139 5259-5262.

Mukherjea R, Castonguay TW, Douglass LW \& Moser-Veillon P 1999 Elevated leptin concentrations in pregnancy and lactation: possible role as a modulator of substrate utilization. Life Sciences $\mathbf{6 5}$ 1183-1193.

Prunier A \& Quesnel H 2000 Nutritional influences on the hormonal control of reproduction in female pigs. Livestock Production Science $\mathbf{6 3}$ $1-16$.

Quinton ND, Laird SM, Kocon MA, Li TC, Smith RF, Ross RJ \& Blakemore AI 1999 Serum leptin levels during the menstrual cycle of healthy fertile women. British Journal of Biomedical Science $\mathbf{5 6}$ $16-19$. 
Ruiz-Cortes ZT, Men T, Palin MF, Downey BR, Lacroix DA \& Murphy BD 2000 Porcine leptin receptor: molecular structure and expression in the ovary. Molecular Reproduction and Development 56 465-474.

Ryan NK, Woodhouse CM, Van Der Hoeck KH, Gilchrist RB, Armstrong DT \& Norman RJ 2002 Expression of leptin and its receptor in the murine ovary: possible role in the regulation of oocyte maturation. Biology of Reproduction 66 1548-1554.

Sokal RR \& Rohlf FJ 1981 Biometry: the principles and practice of statistics in biological research, edn 2. New York, USA: WH Freeman and Co.

Spicer LJ \& Francisco CC 1997 The adipose obese gene product, leptin: evidence of a direct inhibitory role in ovarian function. Endocrinology 138 3374-3379.

Spicer LJ \& Francisco CC 1998 Adipose obese gene product, leptin, inhibits bovine ovarian thecal cell steroidogenesis. Biology of Reproduction 58 207-212.

Stradaioli G, Verini-Supplizi A, Monaci M, Canali C \& Boiti C 1997 Effects of different doses of PMSG on ovarian response and in vitro embryo development in rabbits. World Rabbit Science $\mathbf{3}$ 143-148.

Sweeney G 2002 Leptin signalling. Cellular Signalling 14 655-663.

Tanoue T \& Nishida E 2003 Molecular recognitions in the MAP kinase cascades. Cellular Signalling 15 455-462.

Tartaglia LA 1997 The leptin receptor. Journal of Biological Chemistry 272 6093-6096.
Webb R, Woard KJ \& Armstrong DG 2002 Corpus Luteum (CL) function: local control mechanisms. Domestic Animal Endocrinology 23 277-285.

Zabeau L, Lavens D, Peelman F, Eycherman S, Vandekerckhove J \& Tavernier J 2003 The ins and out of leptin receptor activation. FEBS Letters $\mathbf{5 4 6}$ 45-50.

Zachow RJ \& Magoffin DA 1997 Direct intraovarian effects of leptin: impairment of the synergistic action of insulin-like growth factor-I on follicle-stimulating hormone-dependent estradiol-17 beta production by rat ovarian granulosa cells. Endocrinology 138 847-850.

Zamorano PL, Mahesh VB, De Sevilla LM, Chorich LP, Bhat GK \& Brann DW 1997 Expression and localization of the leptin receptor in endocrine and neuroendocrine tissues of the rat. Neuroendocrinology 65 223-228.

Zhang Y, Proenca R, Maffei M, Barone M, Leopold L \& Friedman JM 1994 Positional cloning of the mouse obese gene and its human homologue. Nature 372 425-432.

Received 4 March 2004

Accepted 14 July 2004

Made available online as an Accepted Preprint 26 July 2004 